\title{
The Implementation of 2013 Curriculum in English Teaching: Stories from Rural Areas
}

\author{
${ }^{1}$ Heri Gunawan, ${ }^{2}$ Afrianto Daud \\ ${ }^{1,2}$ Faculty of Teachers Training and Education, Universitas Riau \\ 1heri.gunawan4688@student.unri.ac.id \\ 2afrianto.a@lecturer.unri.ac.id \\ Principal Contact: 082268284347
}

\begin{abstract}
This study aims to document how 2103 curriculum has been implemented by English teachers in a high school located in a rural area in Riau province. This research in particular investigates the implementation of Scientific Approach by English teachers in Bunga Raya Siak regency. The study is specifically aimed at investigating two research questions: (1) how the scientific approach has been implemented in the classroom, and (2) what problems the teachers face during the implementation. Three English teachers participated in this small scale qualitatitive study. The data were obtained through semi-structured interviews. The findings revealed that the teachers have implemented the scientific approach relatively well. However, the data show that all teachers experienced some problems in implementing the curriculum. In general, the problems can be classified into: (a) insufficient English teaching hour; (b) the students' high diversity in terms of ability; (c) discrepancy between curriculum and national examination contents; and (d) lack of facilities.
\end{abstract}

Keywords: English teaching, implementation, Scientific Approach, Siak Regency

How to Cite: Gunawan, H. and Daud, A. (2018). The implementation of 2013 curriculum in English teaching: Stories from Rural Areas. English Language Teaching Educational Journal, 1(2), 65-75.

\section{INTRODUCTION}

The Indonesian government has been formulating some significant changes and adjustments on the national education system to improve the quality of education. Indonesia has undergone at least ten times curriculum revisions since the Day of Independence. In 2013, the Ministry of Education and Culture or Kemendikbud started to endorse the latest curriculum known as 2013 Curriculum. Having undergone some revisions, 2013 Curriculum is the currently used curriculum ever since. Former Minister of National Education, Muhammad Nuh stated that the main points of 2013 Curriculum development are in refining mindset, strengthening curriculum management, deepening and broadening the materials, reinforcing the learning process, and adjusting the study needs to balance the outcome of the learning process (Kemendikbud, 2013). In spite of the similarities with the previous curricula, 2013 Curriculum has some relatively new features. Among other things, 2013 Curriculum differs in terms of the learning approach recommended to use by teachers known as "Scientific Approach". 
When 2013 Curriculum was firstly introduced, there were some "push and pull" situations regarding its implementation in schools. Many teachers from multiple schools admitted that they were not ready to adopt the new curriculum (Afrianto, 2017). However, as stated in the Regulation of Ministry of Education and Culture (Permendikbud) No. 81A year 2013 about the implementation of 2013 Curriculum, since January 2017, 2013 Curriculum is no longer optional. Consequently, every teacher of any subject including English is mandated to use 2013 curriculum.

One of the learning approaches recommended to use in the 2013 Curriculum is "Scientific Approach". The fundamental idea of the scientific approach is that teachers are suggested to apply the principles or activities that are commonly used in natural science classes. To be more specific, Kemendikbud (2013) explains that the Scientific Approach is an approach that refers to investigating techniques towards some phenomena, acquiring new knowledge, and correcting and combining the background knowledge. The steps of the 2013 Curriculum's Scientific Approach are: observing, questioning, associating, experimenting, and networking.

According to Permendikbud No. 22 year 2016, the learning process using 2013 Curriculum should touch the three domains of education; affection, cognition, and psychomotor. The affective domain is developed with a focus on the substantial transformation of the teaching materials so that the students know about "why". The psychomotoric domain focuses on the substantial transformation of the teaching materials so that the students know about "how". Whereas, the cognitive domain emphasizes the substantial transformation of the teaching materials so that the students know about "what". The expected outcome is the improvement and balance between the ability to be a good person (soft skills) and the ability to be a capable and competent person to have a good life (hard skills) which cover the three competency aspects. With such learning processes, it can be expected that the learning result will yield learners who are productive, creative, and affective, through an integrated reinforcement on affective, cognitive, and psychometric aspects.

As one of the official approaches in the curriculum, every teacher is then expected to be able to implement the Scientific Approach in the learning process, including English teachers in Siak Regency. However, since the approach is considered relatively new to some of the teachers, it is possible that some problems or issues in the implementation will occur. Some studies have investigated how this 2013 Curriculum has been implemented by teachers in the classroom. Yet, most of these studies still focused on schools located in urban areas. A study conducted by Ratnaningsih (2017), for example, found the teachers of a senior high school in Bandung has followed all the five steps in the respective order. Moreover, the teachers can demonstrate the learnercentered learning strengthened by collaborative, cooperative, active and meaningful learning. This seconds the idea that the use of Scientific Approach in learning is able to facilitate the students to achieve the goals of learning.

In addition, a research in Pekanbaru city conducted by Afrianto (2017) found three major problems faced by English teachers when implementing the 
Scientific Approach in class. The three major problems are: (a) challenges to make the students active in learning; (b) intricate procedures of assessment; and (c) lack of supervision on the curriculum implementation. Meanwhile, Hariyanto (2015) in his research found that lack of time and students' active participations were major problems in the implementation. Such problems in the scientific approach implementation are likely to compromise the effectiveness of English teaching and learning process in schools.

Considering all the reasons above, it is necessary to study how English teachers of senior high schools in rural area implement the scientific approach in their classrooms. The school selected as a research site in this study is located in Siak Regency, Riau. It is about 150 kilo meters away from the central city of Pekanbaru. This study is aimed at answering two research questions: (1) how the scientific approach has been implemented in the classroom?; and (2) what problems have the teachers encountered during the implementation? The findings of this research are expected to provide empirical data of the real picture of how teachers implement 2013 Curriculum in district school and what problems that the teachers face in the practice. Therefore, the research findings can be one of the decision making bases to formulate a new policy towards the implementation of 2013 Curriculum.

\section{RESEARCH METHOD}

This research was a qualitative study conducted under interpretive research paradigm. The data processing was dealing with non-numerical data such as sentences, statements, or documents. In other words, the nature object of the research is basically in the forms of qualitative entities such as social phenomena, perceptions, and problems in the process of the Scientific Approach implementation. The qualitative data were gathered through semistructured interviews, followed by its analysis. All three English teachers at a high school in Siak Regency who were actively on duty were chosen to be the participants of the research. Respecting the confidentiality of the research participants, on the paper, the teachers are addressed with their initials instead of their names.

As mentioned above, the data were gathered through in-depth semistructured interviews, which means the interviewee (the participants) were asked a series of questions regarding the scientific approach implementation. In-depth interviews are useful in getting detailed information about a person's thoughts and behaviors or exploring new issues in depth. They are often used to provide context to other data (such as outcome data), offering a more complete picture of what happened in the program and why (Boyce \& Neale, 2006). To do a semi-structured interview, an interview protocol as the basis of initial question was prepared before. It was used as a guide to make sure that the interview does not deviate from the main focus. The interview took about an hour for each participant and it was recorded with a notification and allowance request to the participant before beginning the interview. The recordings of the interview were transcribed and then the transcripts were analyzed. 
In general, the data analysis was done by transcribing, editing, classifying, reducing, and presenting the data. Firstly the recordings of the interviews were transcribed. The transcriptions were checked and edited on the second or third listening. Next, the researcher highlighted some information on the transcripts that is related to the research questions. The highlighted items were then classified based on their group or category. Later, not all information or categories were going to be included or reported on the findings. The data were reduced and then presented in the discussion.

The above-mentioned process of working with the transcripts was done by referring to the three procedures introduced by Flick (2002): open coding (a phase where all themes are found and categorized), axial coding (a stage where the researcher is looking for relationships among themes), and selective coding (a phase where the researcher is choosing the more relevant themes to be further explored in the discussion).

\section{FINDINGS AND DISCUSSION}

\section{The Implementation}

During the interview, one of the question asked was "How do you implement the Scientific Approach in teaching English in the classroom?" This question was intentionally asked to know the teachers' basic understanding about how to carry out teaching using the scientific approach. It is believed that the teachers clear understanding and their positive perception on how to implement the approach will significantly determine the success and the effectiveness of the teaching. Their understanding will guide them in implementing the approach.

When asked about the question, the teachers gave relatively similar answers. They basically described or mentioned some steps in the Scientific Approach. Mr. D, one of the participants, could clearly name all the five steps in the scientific approach. Meanwhile, the other participant, Mr. E did not get to mention the five steps in the scientific approach. He only mentioned two steps; 'observing' and 'questioning'. He, however, confidently stated that by using the scientific approach in the class, his teaching is more directed. He added that the step-by-step activities in the scientific approach is clear and flexible.

"I show a video of, for example, a, uh, speaker, an English native speaker, doing, uh, expressing something. We'll analyze it together, then we, uh, I explain, and we observe. We observe the video, ask, discuss, and analyze uh, the text. Then we try to make the text together, do production, and then performance."

(Mr. D)

"Usually when I teach narrative text, we watch a video, right? After watching the video, uh, I ask the students to give some questions, indirectly." 
In addition to Mr. E's 'incomplete' answer, he stated that the approach was implemented differently during different periods of time. For instance, before 2013 curriculum revisions, teachers were expected to carry out all the steps in the scientific approach in one meeting. However, this was later revised. The steps do not have to be included at one teaching session and the sequence can be altered according to the needs.

The teachers' description of some steps and how they are carried out indicate teachers' full attempt in implementing the approach. The positive results of teachers implementing the scientific approach steps are also shown in some other schools in Indonesia through some studies by Sofyan (2016) and Ratnaningsih (2017). From their studies, it is reported that the teachers shared similar perception in which the scientific approach is regarded as an approach that integrates students' attitude, skill, and knowledge by implementing the steps in the teaching and learning process.

\section{The Problems in the Implementation}

Besides implementation, the results of the semi-structured interviews also revealed some problems in the scientific approach reported by all the participants. The dimension of the problems can be said as something complex. However, in general these problems can be classified into four main issues:

\begin{tabular}{ll}
\hline No. & Problems of the Implementation \\
\hline 1. & insufficient teaching hours \\
2. & students' high diversity \\
3. & discrepant curriculum content \\
4. & lack of facilities \\
\hline
\end{tabular}

In the most recent revision of 2013 Curriculum it is stated that the teaching hour for English subject in high schools is reduced from four hours a week to be two hours a week ( $2 \times 45$ minutes). This reduction, among some other problems, was the problem that most participants complained about. Two of the participants, Mr. D and Ms. B agreed that the time reduction being a problematic issue in the scientific approach implementation. In his interview, Mr. D regretted the reduction of the teaching hour for English subject and stated that the reduced time does not seem to support the students to achieve the standard learning outcomes which he thinks are pretty high. He argued that the time allocation is insufficient for a teacher to carry out all the steps in the approach and therefore cannot meet with the expected goal that the student must achieve. He also added that even with the previous time allocation, it was quite challenging to raise students' achievement in English, let alone with the current situation where the time allocation has been cut.

"The problem of this curriculum is I think in terms of the time reduction, sir. Two hours. Meanwhile, the challenge is high."

(Mr. D) 
"First, the problem is about the time sir, [speaking of] this 2013 Curriculum. Only two hours, from four hours. Consequently, our chance [as a teacher] to give broader knowledge to the student is, uh, limited.'

(Ms. B)

The issue on the time reduction is even more challenging when it meets with the condition of the students. Mr. D and Ms. B stated that the time reduction makes them work really hard to adjust their teaching considering the ability of the students in that area. According to Mr. D, the level of students' ability in this school varies, even most of them are categorized in medium to low level.

"Here [in this school], the ability of the students happens to be very drastic. Some are good, some are not. And some are quiet."

(Mr. D)

"The students' ability is just like what I said before; some are very smart, some others are extremely low."

(Ms. B)

The spirit of 2013 Curriculum is to promote students-centered learning. This is evidenced by the emphasis in the scientific approach whose steps were designed to arouse students' activeness in the class. In questioning step, for instance, the students are expected to be giving some questions about the topic given, not being "informed" by the teacher. Students' low participation clearly becomes a problem that can impede the success of the scientific approach implementation since it can lead to students' passiveness in the class.

When asked about what strategy the teacher use to cope with the limited time and students' diverse ability, both Mr. D and Ms. B gave relatively similar answers. Mr. D said he usually would divide the students into several groups where some of the "top students" were in each group. These top students are the ones who should help their friends in the group to become the teacher's "second mouth". This resembles the finding reported by Hariyanto (2015) saying that lack of time became one of the major problems in the Scientific Approach implementation in one school in Malang. Furthermore, there was a schedule that 2 hours is divided into two, before and after the break time. It made the students did not focus in the material. Thus, the teacher mostly made the discussion in the group rather than individually. Further, the teacher asked the coordinator of each group to manage their members. 
Furthermore, albeit suitable for enjoyable learnings, there seems to be a discrepancy between the contents of 2013 curriculum and the National Exam according to Mr. E. The curriculum, especially the scientific approach, was designed in order to make the learning activity enjoyable. This is true, referring to the Process Standards by Kemendikbud (2013) saying that the teaching and learning process in school should be established in an interactive, inspiring, and fun way in order for students to be active. However, it does not seem to concur with the national examination content in which it requires the students to think analytically.

"In the National Exam, even though [the learning] has been done using 2013 Curriculum, still, the form [of the questions] is about understanding about the text, right? ... Meanwhile in 2013 Curriculum, those are no longer encouraged. ... with the five steps (5M) done, it oddly seems to only result enjoyment, not preparing [the students] for the National Exam."

(Mr. E)

Apparently, this phenomenon occurred not only in Siak. A research by Ratnaningsih (2017) reported a similar case where the teachers conducted active and meaningful learning but the students still lack of critical thinking (HOTS). In addition, although having carried out the learning and teaching activity with various media and creative delivery, the student seemed not to have initiative to learn without stimulation and encouragement from the teacher.

This inconsistency of curriculum contents and National Exam is like leading two things that are supposed to meet to different directions. Even though National Examination is not the ultimate goal of learning, still, the results of the exam contribute certain percent to the students' passing. Many students and parents still view National Exam as the final "battle" that determines the student's future. Therefore, it is no wonder that eventually the National Exam will be taken very seriously by the students. Moreover, the view of students must excel in National Exam will affect the teachers' teaching in some ways, including the using of some methods and strategies. To some of them, the scientific approach has not yet been optimally able to train students to deal with the standardized national exam.

Another problem found in the implementation was in terms of the facilities. This includes both school and students' facilities. The problem regarding the students' facility was in terms of the learning sources or textbooks. One of the major differences between 2013 Curriculum and the previous ones is in terms of the students' independent learning. That is, the principle of learning has shifted from "students are given information from the teacher" to become "students find out the information by themselves" (Permendikbud, 2016). This can be effectively done if the school provides various learning sources to the students. However, according to one of the 
participants, the school did provide textbooks to the students, but not to all. In addition, the students were not supported with modules and/or references books. This condition affected on the effectiveness of the teaching since learning sources play an important role in the teaching and learning using the scientific approach.

In terms of the school facilities, one respondent reported that his school used to operate with no electricity. It was until early 2018 the school finally was facilitated with electricity source. When the research was conducted, the school had just been using the power for six months or so. The creativity of the teacher in teaching using different media was challenged there. The media used to be limited to non-digital ones. The goal to liven up a 'fun and active' learning in the class was rather difficult to actualize.

"The challenge in the implementation of the five steps $(5 \mathrm{M})$ that is very problematic is in [the condition of] village area like here, sir. Like what we'd been through, you know, we've just got the electricity source since the last couple months ago. It was difficult to realize a teacher who is creative, a more creative teacher, a more innovative teacher, like that."

(Mr. E)

Lack of facilities, in terms of both students' and school facilities, has been a huge problem in many schools in Indonesia, especially schools in small towns or rural areas like Siak. Mirroring the problem regarding the lack of facilities in Siak, a research by Amalia (2018) reported that one of the difficulties faced by the teachers in one school in Surakarta was in terms of the classroom facilities. The classrooms were not equipped with functioning pieces of technology that can support teaching and learning activities such as LCD (Liquid Crystal Display) or projectors. That clearly neglected one point in Permendikbud No. 103 year 2013 that explains the use of technology and information is supposed to support and improve the learning efficiently and effectively.

Mulyasa (2009 and 2013) states that the main factor to determine the successful curriculum implementation is teachers' creativity. The teachers are demanded to create students to be productive, creative, and innovative in realizing the aims of learning. One way to realize a creative and innovative learning is with the support of piece of technology in the classroom. If teachers faced problems in implementing the planned program, he/she had to adjust the activities so that learning aims can be achieved. In SMAN 1 Bunga Raya case, let alone having LCDs or projectors, the power source in this school was absent for years. The teachers had to come up with alternative methods in teaching that usually minimize the opportunity to bring a creative and efficient learning. 


\section{CONCLUSION}

Based on the results of the semi-structured interviews, it can be said that the scientific approach has been relatively well implemented by English teachers at this rural area school. This can be seen from the reports which the participants uttered in the interviews. Most respondents could clearly mention the steps in the scientific approach and provide some descriptions about them. This means that the teachers have shown a very positive reception and understanding about the principles of the scientific approach.

However, there is an indication that those steps might not have been implemented in a proper and optimal way. The evidence saying that the teachers sometimes do not include some steps in their classroom can be seen from their interviews when they described what the scientific approach is. One respondent, Mr. D indeed mentioned all the steps in his elaborative answer. Another respondent, Mr. E, by comparison only mentioned two steps (observing and questioning) in his answer to the same question. This could mean either the interviewer did not get to go further to explore Mr. E's answer, or it is fair to say that the teacher did not implement all the steps properly.

There is an indication that it occurs due to the lack or trainings experienced by the teachers. From the interviews, it was discovered that two teachers got once to none training experiences and the other one had experienced trainings several times. This could back up the factor why the implementation has not been done optimally.

Furthermore, an occurrence of some problems during the implementation was inevitable. Among some other problems, insufficient teaching hours and students' extreme diversity were the main issues the teachers expressed during the interviews. In addition to the problem, the mismatch between the contents of the 2013 Curriculum and of the National Exam seems to be another major issue in the implementation. In regard of the time allocation that seems to be one of difficulties that can impede the success of the scientific approach implementation, it is suggested to the government or the policy makers to reconsider the time allocation especially for English subject.

Moreover, up to this point, the training has not reached all the teachers especially those who are in the small cities or rural areas. Due to lack of trainings experienced by teachers in many schools and in order for the teachers to understand on how to implement the scientific approach properly, it is advisable for the government to provide more trainings for all the teachers in near future.

At last, according to the recent revision of 2013 Curriculum, Permendikbud 22/2016, creating is another step in the Scientific Approach. However, since the teachers in SMAN 1 Bunga Raya Siak have not been familiar with this step, this research did not get to investigate the creating step. Therefore, a further research investigating this matter is recommended to add and study the creating step in the implementation. In addition, the data from the semi-structured interviews might have not been able to vividly report what actually happened in the class due to some limitations of the methodology 
aspect of the study. Therefore, the other researchers are hoped to do better researches by employing the technique which had not been implemented by the researcher in this present study such as observation or field study.

\section{REFERENCES}

Afrianto. (2017). The implementation of scientific approach for teaching English in Senior High School: voices from the field. Advances in Social Science, Education and Humanities Research (ASSEHR) 110: 186-191.

Amalia, S. (2018). A Study on the Implementation of Scientific Approach of 2013 Curriculum in English Teaching Process at Twelfth Grade of SMK Sakti Gemolong in 2017/2018 Academic Year. Thesis. Surakarta: The State Islamic Institute of Surakarta.

Boyce, C. \& Neale, P. (2006). Interviews: A Guide for Designing and Conducting In-Depth Interviews for Evaluation Input. Pathfinder.

Flick, U. (2002). An introduction to qualitative research. London: Sage Publication.

Hariyanto, I.P.D. (2015) A Study on the Implementation of Scientific Approach Used by English Teacher in Teaching English to Low Level Students at SMP in Malang. S1 Thesis. Malang: University of Muhammadiyah Malang.

Kemendikbud. (2013). Materi Pelatihan Guru Implementasi Kurikulum 2013 SMP/MTs. Jakarta: Kementrian Pendidikan dan Kebudayaan.

Kemendikbud. (2013). Permendikbud No. 81A/2013 - Implementasi Kurikulum: Pedoman Umum Pengajaran. Jakarta: Kementrian Pendidikan dan Kebudayaan.

Kemendikbud. (2014). Permendikbud No. 103/2014 - Pembelajaran pada Pendidikan Dasar dan Menengah. Jakarta: Kementrian Pendidikan dan Kebudayaan.

Kemendikbud. (2016). Permendikbud No. 22/2016 - Standar Proses Pendidikan.

Mulyasa, H. E. (2009). Implementasi Kurikulum Tingkat Satuan Pendidikan: Kemandirian Guru dan Kepala Sekolah. Jakarta: Bumi Aksara. 
Mulyasa, H. E. (2013). Pengembangan dan Implementasi Kurikulum 2013. Bandung: PT Remaja Rosdakarya.

Mustafa, Z. (2009). Mengurangi Variabel Hingga Instrumentasi. Jakarta: Graha Imu.

Polit, D.F. \& Hungler, B.P. (1995). Nursing research principles and methods. $3^{\text {rd }}$ edition. Philadelphia: JB Lippincott.

Ratnaningsih, S. (2017). Scientific approach of 2013 curriculum: Teachers' implementation in English language teaching. English Review: Journal of English Education, 6(1), 33-40. DOI: 10.25134/erjee.v6i1.768

Sofyan, A. (2016). The Implementation of Scientific Approach in English Teaching Based on 2013 Curriculum in SMK Negeri 2 Sragen in the Academic Year of 2015/2016. Thesis. Surakarta: Universitas Muhammadiyah Surakarta.

http://sekolah.data.kemdikbud.go.id. 